\title{
FRANCE'S POLICY TOWARDS UKRAINE IN THE CONTEXT OF THE UKRAINIAN - RUSSIAN WAR
}

\section{ПОЛІТИКА ФРАНЦЇ̈ ЩОДО УКРАЇНИ У КОНТЕКСТІ УКРАЇНСЬКО - РОСІЙСЬКОї ВІЙНИ}

\section{ПОЛИТИКА ФРАНЦИИ ПО ОТНОШЕНИЮ К УКРАИНЕ В КОНТЕКСТЕ УКРАИНСКО - РОССИЙСКОЙ ВОЙНЫ}

\section{Denysenko K.Yu.}

$\mathrm{PhD}$ in Political Sciences, Associate Professor at the International relations and foreign policy chair of the Institute of International Relations of Taras Shevchenko National University of Kyiv. E-mail: mvi.dkyu@ clouds.iir.edu.ua

\section{Kovtun O. Yu.}

$\mathrm{PhD}$ in Political Sciences, Associate Professor at the International Organizations and Diplomatic Service Chair of the Institute of International Relations of Taras Shevchenko National University of Kyiv. E-mail: mod.koyu@clouds.iir.edu.ua

\section{Денисенко К.Ю.}

Кандидат політичних наук, доцент кафедри міжнародних відносин та зовнішньої політики Інституту міжнародних відносин Київського національного університету імені Тараса Шевченка Е-таil: mvi.dkyu@clouds.iir.edu.ua

Ковтун О.Ю.

Кандидат політичних наук, доцент, кафедри міжнародних організацій та дипломатичної служби Інституту міжнародних відносин Київського національного університету імені Тараса Шевченка Е-таil: mod.koyu@clouds.iir.edu.ua

\section{Денисенко К.Ю.}

Кандидат политических наук, доцент, кафедры международных отношений и внешней политики Института международных отношений Киевского национального университета имени Тараса Шевченко E-mail: mvi.dkyu@clouds.iir.edu.ua

\section{Ковтун Е.Ю.}

Кандидат политических наук, доцент, кафедры международных организаций и дипломатической службы Института международных отношений Киевского национального университета имени Тараса Шевченко Еmail: mod.koyu@clouds.iir.edu.ua

Abstract. The article discusses the influence and the risks from France's rapprochement with the Russian Federation in the aftermath of Ukrainian - Russian war, what can present a threat to the EU Neighborhood Policy. The ideas and views expressed in the article, present exclusively the point of view of authors, who relied on a wide range of documents and official information from open sources, but they do not necessarily have to coincide with the opinion of other specialists. Currently expressing the desire to get Russia back to the dialogue with the European Union, which throughout the history defined Moscow as one of the main economic partners, France pursues the policy of appeasing the aggressor, neglecting the war in Ukraine. The Russian Federation violated the basics of the international law, having annexed the Crimean Peninsula and having occupied certain areas of Donetsk and Lugansk regions. The article underlines that Ukraine is not alone in the long least of Moscow pro-imperial plans and presents a threat to the stability and security of the continent. The analyses, also demonstrates the politics of France towards Ukraine during the last seven years. The article provides a complex evidence that there is a connotation between the Ukrainian - Russian war and the desire of Moscow to establish the instability zone along the borders of the European Union.

Keywords: France, Russia, Ukraine, bilateral relations, conflict resolution. 
Анотація. У статті розглядається вплив та ризики зближення Франиії з Російською Федерацією у контексті украӥнсько-російської війни, щуо може становити загрозу для політики сусідства ЄС. Ідеї та погляди, викладені в статті, представляють виключно точку зору авторів, які спиралися на широкий спектр документів та офіиійної інформації $з$ відкритих джерел, але вони не обов'язково повинні збігатися з думкою інших дослідників. Висловлюючи бажання повернути Росію до діалогу з Європейським Союзом, Франція яка протягом усієї історії визначала Москву одним із головних своїх економічних партнерів, проводить політику умиротворення агресора, нехтуючи війною в Украӥні. Російська Федерація порушила основи міжнародного права, анексувавши Кримський півострів та окупувавши окремі райони Донеиької та Луганської областей. У статті підкреслюється, щяо Україна не є останнім пунктом у проімперських планах Москви $i$ вона становить безпосередню загрозу стабільності та безпеці континенту. Дослідження також показує політику Франиії щодо України протягом останніх семи років. У статті наводяться докази того, щзо існує прямий зв'язок між украӥнсько-російською війною та бажанням Москви створити зону нестабільності вздовж кордонів Свропейського Союзу.

Ключові слова. Франція, Росія, Україна, двосторонні відносини, вирімення конфліктів.

Аннотация. В статье рассматривается влияние и риски сближения Франции с Российской Федераџией в контексте украинско-российской войнь, что может представлять угрозу политике соседства ЕС. Идеи и взгляды, изложенные в статье, представляют исключительно точку зрения авторов, опиравшихся на широкий спектр документов и официальной информачии из открытых источников, но они не обязательно должны совпадать с мнением других исследователей. Выражая желание вернуть Россию к диалогу с Европейским Союзом, Франция, которая на протяжении всей истории определяла Москву одним из главных своих экономических партнеров, проводит политику умиротворения агрессора, пренебрегая войной в Украине. Российская Федераџия нарушила основы международного права, аннексировав Крымский полуостров и оккупировав отдельные районы Донеикой и Луганской областей. В статье подчеркивается, что Украина не является последним пунктом в проимперских планах Москвы и представляет непосредственную угрозу стабильности и безопасности континента. Исследование также показывает политику Франции в отнотении Украины за последние семь лет. В статье приводятся доказательства, что существует прямая связь между украинско-российской войной и желанием Москвы создать зону нестабильности вдоль грании Европейского Союза.

Ключевые слова. Франция, Россия, Украина, двусторонние отночения, разрешение конфликтов.

Introduction. In the aftermath of the COVID-19 pandemic, Brexit, migration challenges, in the nearest future the European Neighborhood Policy can become another matter of concern due to the growing rapprochement between France and the Russian Federation.

The annexation of Crimea and the war in Donbas were the key events of the 2014, which directly influenced not only the post-soviet space and the European Security, but the entire international system. The European Union as well as other countries of the world had to revise their politics regarding Russian Federation. France was not an exception in this context. Until 2014, France never showed bold support for Kyiv. Ukraine never belonged to the Paris historical sphere of interests and was always associated with Moscow. The French government rarely paid deep attention to the political situation in Ukraine.

Even the former French President François Hollande, who was a direct participant of the Minsk agreements, was inclined to view the war in Donbas, not as it really is, the aggressive war of Russia against Ukraine, but rather a kind of internal conflict with Russia's support of "separatists" (Olland, 2019). French political and business elite were convinced that the EU has already achieved 
the final point of enlargement and it is a bad idea to support integration hopes of pro-western Ukrainian political elite (Yevropeiska pravda, 2016).

Ukraine is not important for France in terms of political and economic interests. Even though some observers speak about the intensification of Ukrainian - French contacts, both presidents met more than, ten times in different formats, neither François Hollande, nor Emmanuel Macron never officially visited Kyiv. In July 2019, the Kremlin's press service reported that the French leader had accepted the invitation to pay a visit to Moscow on the occasion of the 75th anniversary of the Second World War victory (TASS, 2020). But the visit was canceled due to COVID-19 pandemic.

France also doesn't have serious economic interests in Ukraine. In 2014 Ukraine was ranked 54-th in French exports and 67-th in imports (Narochniczkaya, 2019). According to the results of 2019, France ranked 8th among Ukraine's trading partners among European countries with a share of $4.65 \%$ of total turnover, as well as 9th place among countries in terms of investment in Ukraine's economy (Ambassade d'Ukraine en France, 2021).

The active and the dynamic support of the dialogue with the Russian Federation is one of the main challenges for the future of Ukraine - France relations. In this article, the present-day relations of Ukraine and France is interpreted in the context of the Ukrainian conflict and the rapprochement of France and the Russian Federation, what poses a threat to the European Neighborhood Policy.

Definitions, methods, and research structure. The subject matter of the study is the foreign policy of France towards the Russian Federation in the contacts of the Ukrainian - Russian war. The hypothesis of this paper is the following: France under the presidency of Emanuel Macron seeks to return Moscow to the dialogue with the European Union, acting as the ambassador to a country that has launched hostilities against its own neighbor. The aim of the article is to show that this approximation presents a serious threat to the stability and security of the whole Europe. With this purpose the authors plan to answer such questions: the peculiarities of the Ukrainian - French relations in recent years; The specifics of France's foreign policy strategy towards the Russian Federation and weather the economic interests of one of the European Union members is more important than Common Security and Defence Policy.

The methodological basis of the research is the systematic approach which helped the authors to study the foreign policy of France in recent years. The content analysis method was used for the analysis of a great number of textual and visual information from different electronic and non-electronic resources. The comparative method allowed us to obtain reliable conclusions considering the bilateral relations between France - Ukraine - Russia. The descriptive method helped to present the results of the study in the logical sequence. But, as we consider, the case study became the main method of this research paper, because the authors tried to make the analysis of the present-day situation with the settlement of the conflict in Eastern Ukraine.

The situation is very specific because it deals with the violation of the international law on the occupied territories and in the Crimea by the neighboring state that is the Permanent member of the UN Security Council and possesses the military doctrine with the possibility of preventive nuclear attack and presents threat to the entire European continent.

Literature review and research background. Due to the actuality of the problem, it is already visible that the problem lacks fundamental research such as monographs and articles particularly about the foreign policy of France under the presidency of Emmanuel Macron. Of course much has already been written, covering the issues of bilateral relations of France with Russia and Ukraine such as: "Les leçons du pouvoir", written by François Hollande the former President of France (Hollande, 2018), "Revolution Française: Emmanuel Macron and the quest to reinvent a nation" written by Sophie Pedder in which she examines the first year in office of France's youngest and most exciting president in modern times (Pedder, 2018), the article of Andrii Kutsenko "Emmanuel Macron and Franco-Russian relations at the present stage" (Kutsenko, 2020), but it is still hard to find appropriate materials, covering the problem. Official documents such as: "The UN General Assembly Resolution 68/262 on territorial integrity of Ukraine, adopted by the General Assembly on 27 March 2014" (UN General Assembly, 2014), Minsk agreement 
(UNIAN,2015), speech by the President Emmanuel Macron at the Ambassadors' Conference, 2018 (The Ministry for Europe and foreign affairs of France, 2018), "Conclusions agrées. Sommet de Paris en format "Normandie" (Palais de l'Elysée, 2019) also became the vital part of the research.

The specific of the research is also notable in the context of the absence of the deep analytical materials of the French researches. Such situation has some reasons and explanations: French - Ukrainian relations are not the priority for the country. Ukraine is more studied in the context of the Russian Federation, which was always a priority for Paris.

Materials of the research. In 2014, French President François Hollande supported the EU policy of sanctions against the Russian Federation. Russia illegally annexed Crimea in February, 2014. Russian militants invaded the territory of Ukrainian Donbas in April 2014 after the Russian Federation seized Crimea.

Russia's politics in the annexed Crimea and on the temporarily occupied territories of Donbas is an element of the hybrid war against Ukraine. The instruments of this war are very different: the military aid (the weapons and ammunition delivery; the military and security advisers; the direct military actions (the shelling of the Ukrainian territories and airspace ( $\mathrm{MH}-17$ case); the direct invasion (Ilovaysk and Debaltseve operations), the financial support of the separatist and proxies; so called humanitarian convoys (used as the channel for the transportation of ammunition, equipment and other resources); the information and the media campaigns (so called "Novorossiya" or "people's republics" projects), human rights violation, also the creation of a background for effective implementation of the "Russian world" concept, one of the basic pillar that is a religious unity of the "fraternal nations". The establishment of the "grey zones" is one of the key elements of Russia's foreign policy towards its neighbors.

Realizing the negative consequences for itself, Paris couldn't back down from the policy of European solidarity, which lied in the condemnation of Moscow's aggressive actions in Ukraine. France terminated its military contract, signed with Russia in 2010 for the construction of two universal landing helicopter ships ("Mistrals"). The total payment from France was more than one billion euros. What considerably hurt the budget of the country (Deutsche Welle, 2015).

France recognized that the annexation of Crimea was illegal and joined the UN General Assembly resolution 68/262, confirming the sovereignty and territorial integrity of Ukraine (UN General Assembly, 2014). France took an active part in the negotiations of the Minsk agreements both in September 2014 and in February 2015. It was the French President - François Hollande, who proposed the initiative of the "Normandy format talks" (Nenartovych, 2017). The first meeting of leaders of Germany, Ukraine, France and Russia took place during the celebration of the 70-th anniversary of the allies landing in Normandy during the Second World War. The result of the talks was a new package of measures called Minsk II (a set of measures to implement Minsk agreements), which was agreed on February 12-th, 2015 (UNIAN, 2015).

Another initiative of France was the "Moral plan", which was supposed to help the West and Russia to find a compromise for a peaceful solution of the Donbas conflict. Pierre Moral, chairman of the working group on political affairs of the Trilateral Contact Group (TCG), consisting of the representatives from Ukraine, the Russian Federation and the Organization for security and cooperation in Europe (OSCE), offered the Ukrainian Parliament to adopt a special law which will allow to carry out separate Donbas elections. The elections would be held in accordance with the Ukrainian legislation, but Kyiv should give the so-called "republics" the possibility to stage them on their own rules. The Morel Plan didn't find support in Kyiv. Ukrainian President Petro Poroshenko said that he considered it to be nothing more than Morel's personal opinion (Deutsche Welle, 2015).

The election of Emanuel Macron as the President of France in May 7, 2017 didn't fundamentally change the French position on Crimea, Ukraine and Russia - EU relations. In the context of the analysis, it is worth mentioning, that in January 21, 2016 as the French Finance Minister, E. Macron visited Moscow and in contradiction to the official position of the government, expressed hope that the anti-Russian sanctions would be postponed no later than August of this year ( Yevropeiska pravda 2016). During the elections E. Macron underlined the necessity to have the 
dialogue with Moscow and promised to have "demanding talks" with Vladimir Putin. It is vital to underline, that E. Macron very seldom touched Ukraine and Donbas in his election speeches, while his opponent Marine Le Pen (the President of the National Rally, previously National Front), didn't hide her sympathy for Moscow and recognized the annexed Crimea as the part of the Russian Federation.

Having won the elections E. Macron demonstrated the noticeable interest to the continuation of the "Normandy format talks" and even talked about the possibility to expand sanctions if Russia doesn't stop supporting separatists in Donbas (Russian "humanitarian convoy" to Ukraine - a military, financial and humanitarian assistance from Russian Federation to militants and the population of so-called "DNR" and "LNR" during the war in Eastern Ukraine. More than 70 trucks have crossed the Ukrainian - Russian border with such assistance since 2014). The French President even pushed forward to announce that he reached the agreement with Vladimir Putin to hold a summit of the "Normandy quartet" during their meeting in Versailles on the 29-th of May, 2017. For V. Putin, it was the first meeting with a French President in five years. He canceled a meeting with Macron's Francois Hollande scheduled for October 2016 after F. Hollande called Russia's airstrikes on Aleppo a war crime (Deutsche Welle, 2017). In Versailles, E. Macron obviously demonstrated his commitment to the Russian President and his desire to return Moscow to the dialogue with the EU. However, from May 2017 to May 2019 there were only few telephone talks (summer 2017), one meeting of ministers in June 2018 in Berlin and a tripartite summit of A. Merkel, E. Macron and P. Poroshenko without Vladimir Putin on May 10, 2018 in Aachen. This day the President of France received the international award of Charlemagne Prize for his "vision of a new Europe" (Interfax, 2018).

In his annual address to the French diplomatic corps (the conference of ambassadors) on August 27, 2018, E. Macron underlined the necessity to engage to a broad discussion of defense and security issues of all European partners, including Russia. He also pointed that the substantial progress towards resolving the Ukrainian crisis in compliance with the OSCE framework will clearly be the prior condition necessary for real progress with Moscow (The Ministry for Europe and foreign affairs of France, 2018).

On August 21, 2019 E. Macron announced the possibility of the "G8" format restoration, but only after the settlement of the conflict on the East of Ukraine (Radio Free Europe, 2019).

In his annual conference of ambassadors on August 27, 2019 E. Macron pointed again that Russia is also the part of Europe and if the European countries are unable to accomplish anything useful with Russia at any given time, they will remain in a state of deeply unproductive tension. Europe will continue to be the theatre of a strategic battle between the United States and Russia, with the consequences of the Cold War still visible. Only one sentence is devoted to the RussiaUkraine conflict in which it is said that the date of the next summit will be offered in the coming days (Ambassade de France à Riga, 2019).

Before the summit in Biarritz which was held from the 24-th to the 26-th of August, 2019 the President of France met with Vladimir Putin in his summer residence, Fort de Brégançon. During the negotiations, E. Macron was trying to reach the progress in resolving the situation in Eastern Ukraine. Both presidents agreed that they do not mind that the "Normandy format talks" would continue to remain the main platform of dialogue for the conflict resolution. The implementation of the Minsk agreements remained one of the main conditions. At the same time both leaders of France and Russia expressed the expectation that the change of power in Ukraine and the election of Vladimir Zelensky, will give the new impulse for the settlement of the conflict (AP, 2019).

On December 9, 2019 the "Normandy format talks" summit was held in Paris. The meeting was initiated by the President of France - Emmanuel Macron. The fact of such negotiations after a three year break was called an achievement (Deutsche Welle, 2019).

The final communiqué contains the next concrete steps to resolve the situation in Donbas, including the termination of a ceasefire by the end of this year, as well as the exchange of detainees in an "all for all" format also by the end of this year. Other agreed measures also include the 
deployment of forces in three additional areas by the end of March 2020, the opening of the new entry-exit checkpoints and support for demining measures. The communiqué also emphasizes that the OSCE monitoring mission should have access throughout Ukraine for the full implementation of its mandate (Palais de l'Elysée, 2019). Regarding the political part of Minsk agreements, the final part of the document of the summit states that the parties consider it necessary to assign the provisions of the so-called "Steinmeier formula" in Ukrainian legislation in accordance with the agreements reached earlier. The "Steinmeier formula" is a package of proposals of a President of Germany -Frank-Walter Steinmeier, who offered to hold the elections on the temporarily occupied territories of Donetsk and Lugansk regions under the control of the OSCE representatives and grant a special status to these territories [(Deutsche Welle, 2019).

It is important to pay attention to the privileged attitude of $\mathrm{E}$. Macron to V. Putin during the meeting. The head of the Russian Federation received the largest motorcade and near the Élysée Palace, the President E. Macron warmly embraced the Russian leader. Moreover, for the first time V. Putin wasn't late and arrived in time, what can also be interpreted as a manifestation of commitment to the President of France (Hromadske International, 2019). But the final rapprochement of two presidents took place a few weeks later when they discussed by phone the achievements of the Paris Summit (The Ministry for Europe and foreign affairs of France, 2020).

The attitude of E. Macron towards the Donbas war and the relationships with Russia changed dramatically in 2020. In an interview on January 15, 2020 the President of France said that he is ready for closer with the Russian Federation despite its long-lasting conflicts with its neighbors. E. Macron said that his position is the result of a long analysis and reflections. The President of France stated: "Russia has captured Ukraine and we took measures. We are on the way to resolving frozen conflicts, but while we are waiting for their solution, it is time to start moving forward" (Palais de l'Elysée, 2020).

In March - April 2020, E. Macron called the states to the global truce at the time of the COVID-19 pandemic. The president suggested that V. Putin "would probably agree with him", hinting about al least a partial cessation of hostilities on the territory of Ukraine"(CNN, 2020). Speaking at the Munich Security Conference on the 20-th of February this year which Vladimir Putin skipped for the second time, E. Macron called the international community to rebuilt the overall security architecture, which should include the dialogue with Russia. France and Germany called all parties of the conflict to take the responsibility for the lives of people who are in a threat because of the pandemic (HLAVKOM, 2021).

For now it is not quite clear what will be the politics of France to the war in Ukraine in the future, but as we see E. Macron will coordinate the foreign policy of France with the need of close cooperation between France and Russia. Even though France condemned the annexation of the Crimean Peninsula and generally continues to play an active role in the direction of the final settlement of the conflict, the relationships with the Russian Federation is still the main priority. At least, France started to follow the events in Ukraine, because the conflict takes place along the border of the European Neighborhood Policy and deeply affects French political and economic ties with Moscow.

Conclusions and discussions. On the one hand the French diplomacy doesn't have the purpose to step back from the EU official position which lies in the condemnation of Russia's aggressive actions in Ukraine, but on the other, E. Macron's administration doesn't see the alternative of conflict resolution rather than "Normandy format talks"' and call upon Europe to get back to the dialogue with Moscow. The President of France considers Russia away from Europe as the major strategic error. The Paris has picked up for itself the significance of cooperation with Russia and less action in dealing with Ukraine. In his book "Les Pensees du General de Gaulle" a well - known French politician and a former Henri Guaino member of the National Assembly wrote: "A mistake that can be read in particular in the difficulties of European construction is the need of merging all European nations without taking into account history and culture. The failure 
can be seen in relations between Russia and Ukraine, where Europe and the United States have ignored geography and culture (Guaino, 2015).

But, we consider that it is necessary to remind about the appeasement and what role did it play in the world history and French foreign policy, when it failed to stop the Nazi Germany.

Thus, the official position of France lies in the adherence to the "Normandy format talks" in tandem with Germany, speaking on behalf the European Union and the further expansion of closer ties with the Russian Federation.

\section{References}

1. Ambassade de France à Riga. (2019, August 27). Ambassadors' conference Speech by M. Emmanuel Macron, President of the Republic. https://lv.ambafrance.org/Ambassadors-conference-Speech-by-M-Emmanuel-Macron-President-ofthe-Republic

2. Associated Press (AP). (2019, August 19). Putin, Macron holds French-Russian talks before G-7. https://apnews.com/article/7faa25f61c6640daa1a6d7bfee5c8442

3. CNN. (2020, April 4). France's president says US and China back a world truce -and he thinks Putin will "definitely agree". https://edition.cnn.com/2020/04/15/world/macronworld-truce-putin-intl/index.html

4. Deutsche Welle. (2015, August 31). Paryzh vernul Moskve denhy za «Mystraly». https://www.dw.com/ru/сми-париж-вернул-москве-деньги-за-мистрали/a-18684337

5. Deutsche Welle. (2015, March 15). The Morel Plan: Will Kyiv swallow the bitter pill?. https://www.dw.com/en/the-morel-plan-will-kyiv-swallow-the-bitter-pill/a-18756951

6. Deutsche Welle. (2017, May 25). French and Russian presidents meet in Versailles. https://www.dw.com/en/french-and-russian-presidents-meet-in-versailles/a-38981587

7. Deutsche Welle. (2019, December 10). Deviat hodyn perehovoriv: yak u Paryzhi proishov samit "normandskoi chetvirky". https://www.dw.com/uk /девять-годин- переговорів-яку-парижі-пройшов-свміт-нормандської-четвірки/а-51603096

8. Deutsche Welle. (2019, December 10). Na samiti v Paryzhi domovylysia pro obmin utrymuvanymy ta povne prypynennia vohniu. https:/www.dw.com/uk/на-саміті-в-парижідомовилися-про-обмін-утримуваними-та-повне-припинення-вогню/а-51602582

9. Guaino, H. (2015, April 5). De Gaulle, la France et moi. http://www.gaullisme.fr/2015/04/05/henri-guaino-de-gaulle-la-france-et-moi/

10. HLAVKOM. (2021, February 20). Makron na Miunkhenskii konferentsii vyslovyvsia $z a$ dialoh $z$ Rosiieiu. https://glavcom.ua/world/observe/makron-na-mjunhenskij-konferentsijivislovivsja-za-dialog-z-rosijeju-737850.html

11. Hollande, F. (2018). Les leçons du pouvoir. Stock. P.288.

12. Hromadske International. (2019, December 10). A Tie so Far: Tricky Talks With Tough People in Paris. https://en.hromadske.ua/posts/a-tie-so-far-tricky-talks-with-tough-peoplein-paris

13. Interfax-Ukraine. (2018, May 4). Poroshenko, Merkel, Macron to meet in Aachen on May. https://en.interfax.com.ua/news/general/503105.html

14. Kutsenko, A. (2020). Emmanuel Macron and Franco-Russian relations at the present stage. Political Science and Security Studies Journal, 1(1), 94-100.

15. Ministerstvo zakordonnykh sprav Ukrainy. (2021, February 1). Dvostoronnie torhovelno-ekonomichne spivrobitnytstvo mizh Ukrainoiu ta Frantsiieiu. https://france.mfa.gov.ua/spivrobitnictvo/289-torgovelyno-jekonomichne-spivrobitnictvo-mizhukrajinoju-ta-francijeju

Narochniczkaya, E. (2019, May 24). Ukrainskij konflikt i Krym: ispytanie franczuzskoj diplomatii.

http://www.perspektivy.info/oykumena/politika/ukrainskij_konflikt_i_krym_ispytanije_francuzskoj _diplomatii_2019-05-24.htm 
16. Nenartovych, Y. (2017). Franko-Rossyiskye otnoshenyia v peryod Prezydenstva F. Olannda (2012-2017). https://elib.bsu.by/bitstream/123456789/190116/1/50-52.pdf

17. Olland, F. (2019). Uroki vlady. Kharkiv, Folio. p.76 - 77.

18. Palais de l'Elysée. (2019, December 9). Conclusions agrées. Sommet de Paris en format "Normandie". December 2019 - Declaration. https://www.elysee.fr/front/pdf/elyseemodule-14873-fr.pdf

19. Palais de l'Elysée. (2019, December 9). Conclusions agrées. Sommet de Paris en format "Normandie". December 2019 - Declaration. https://www.elysee.fr/front/pdf/elyseemodule-14873-fr.pdf

20. Palais de l'Elysée. (2020, January 15). Voeux du President de la Republique a la presse. https://www.elysee.fr/emmanuel-macron/2020/01/16/voeux-du-president-de-la-republiquea-la-presse

21. Pedder, S. (2018). Revolution Française: Emmanuel Macron and the quest to reinvent a nation. Bloomsbury Continuum. P.320.

22. Radio free Europe. (2019, August 21). Macron: Russia Can't Return To G8 Format Before Ukraine Crisis Solved. https://www.rferl.org/a/macron-russia-can-t-return-to-g8-formatbefore-ukraine-crisis-solved/30122104.html

23. TASS - Russia News Agency. (2020, February 5). Macron's visit to Moscow on Victory Day reflects approach to ties with Russia, says envoy. https://tass.com/world/1116933

24. The Ministry for Europe and foreign affairs of France. (2018, August 27). Speech by President Emmanuel Macron - Ambassadors' Conference 2018. https://www.diplomatie.gouv.fr/en/the-ministry-and-its-network/news/ambassadorsweek/ambassadors-week-edition-2018/article/speech-by-president-emmanuel-macron-ambassadorsconference- 2018

25. The Ministry for Europe and foreign affairs of France. (2018, August 27). Speech by President Emmanuel Macron - Ambassadors' Conference 2018. https://www.diplomatie.gouv.fr/en/the-ministry-and-its-network/news/ambassadorsweek/ambassadors-week-edition-2018/article/speech-by-president-emmanuel-macron-ambassadorsconference-2018

26. The Ministry for Europe and foreign affairs of France. (2020, January 3). Conversation between M. Emmanuel Macron, President of the Republic, and Mr. Vladimir Putin, President of Russia - Communiqué issued by the Presidency of the Republic.

https://www.diplomatie.gouv.fr/en/country-files/russia/news/article/conversation-betweenm-emmanuel-macron-president-of-the-republic-and-mr

27. UN General Assembly. (2014, March 27). Resolution adopted by the General Assembly on 27 March 2014, 68/262 Territorial integrity of Ukraine. https://www.securitycouncilreport.org/atf/cf/\%7B65BFCF9B-6D27-4E9C-8CD3CF6E4FF96FF9\%7D/a_res_68_262.pdf

28. UN General Assembly. (2014, March 27). Resolution adopted by the General Assembly on 27 March 2014, 68/262 Territorial integrity of Ukraine. https://www.securitycouncilreport.org/atf/cf/\%7B65BFCF9B-6D27-4E9C-8CD3CF6E4FF96FF9\%7D/a_res_68_262.pdf

29. UNIAN. (2015, February 12). Minsk Agreement: Full text in English. https://www.unian.info/politics/1043394-minsk-agreement-full-text-in-english.html

30. Yevropeiska pravda. (2016, June 14). Soiuznyk mymovoli. Choho chekaty Ukraini vid spivpratsi z Frantsiieiu https://www.eurointegration.com.ua/articles/2016/06/14/7050703/ 